\title{
Copper affect the multixenobiotic resistance mechanism (MXR) in embryo and larvae of Rhamdia quelen
}

\author{
Oliveira Ribeiro, C.A. ${ }^{1 *}$, Azevedo, A.C.B. ${ }^{1}$; Bombardelli, R.A. ${ }^{2}$ \& Randi, M.A.F. ${ }^{1}$ \\ ${ }^{1}$ Laboratório de Toxicologia Celular, Departamento de Biologia Celular PO Box: 19031. Universidade Federal do Paraná. \\ CEP:81.531-990 Curitiba, PR, Brazil \\ ${ }^{2}$ Instituto de Pesquisas em Aquicultura Ambiental - InPAA - UNIOESTE. Toledo, Paraná, Brasil
}

Received December 09, 2020; Accept October 06, 2021

\begin{abstract}
P-glycoproteins (P-gp) and Multidrug resistance protein (MRP) represent a family of ABC (ATP-binding cassette) transporters responsible for multixenobiotic resistance mechanism (MXR) in aquatic organisms. In the current study the modulation of P-gp and MRP proteins was evaluated in embryo and larvae of Rhamdia quelen fish species exposed to copper. Adult females were exposed by gavage during 60 days to copper $(5 \mathrm{mg} \mathrm{Cu} \mathrm{kg-1)} \mathrm{and} \mathrm{eggs,} \mathrm{embryos,} \mathrm{and} \mathrm{larvae} \mathrm{from} \mathrm{exposed} \mathrm{and} \mathrm{unexposed}$ females were exposed to $30 \mathrm{mg} \mathrm{Cu} \mathrm{L-1}$. The activity of ABC transporters was accessed via calcein accumulation assay using the specific inhibitors: Verapamil (P-gp) and MK571 (MRP). P-gp activity was detected in all analyzed stages whereas MRP activity was observed after 36 and 96 hpf. Oocytes from females previously exposed and larvae stages (36 and 96 hpf) accumulated less calcein than no exposed oocytes, showing higher $\mathrm{ABC}$ transporters activity. In individuals exposed to copper, a higher inhibitory effect was observed $1 \mathrm{hpf}$. The modulation of $\mathrm{ABC}$ transporter proteins is time dependent throughout the development, and the initial stages are more sensible to copper. These findings highlight the MXR mechanism as a biomarker of pollutant exposure in early stages of development of $R$. quelen.
\end{abstract}

Keywords: MXR mechanism, Rhamdia quelen, inorganic copper, biomarkers, early development stages.

\section{INTRODUCTION}

The super-family of transport proteins ABC (ATP-binding cassette) are highly conserved transmembrane proteins (Dean \& Annilo, 2005), and some of its members are related with those of the aquatic organisms known as multixenobiotic defense mechanism (MXR). The MXR is like the multidrug resistance mechanism (MDR), found in tumor cell lines of mammals as the result of low intracellular accumulation of anti-cancer drugs (Locher, 2016).

$\mathrm{ABC}$ transporters act as efflux pumps reducing the intracellular accumulation of endogenous metabolites and xenobiotic compounds, hence protecting exposed organisms from possible toxic effects of chemicals (Litman et al., 2001). Moreover, it has been shown that some compounds can decrease or inhibit the activity of the transport both in vitro (Oosterhuis et al., 2008) and in vivo, leading to the increase in the intracellular concentration of xenobiotics potentiating the effect of these toxic compounds (Bošnjak et al., 2009). Chemicals that inhibit the transporters associated with the MXR are described as chemosensitizers agents classified into two categories: (1) competitive inhibitors with high affinity that prevent the binding and consequently the active transport of other substrates; and (2) non-competitive, blocking the ATPase activity of transporters (Faria et al., 2011).

The MXR was described in a diversity of organisms and is related with $\mathrm{P}$-glycoprotein (P-gp, $\mathrm{ABCB}$ ) and multidrug resistance protein (MRP, $\mathrm{ABCC}$ ). According to Zaja et al. 2008) and Lončar et al. (2010) the activity of these proteins presents a relevant role in ecotoxicological context. The P-gp 
is primarily involved in the efflux of various unmodified xenobiotics (phase 0 of cellular detoxification) (Szakács et al., 2008) while the MRP substrates are mainly phase I and II detoxification metabolites conjugated with glutathione (GSH) or glucuronic acid (GA) sulfate. According to Xu et al. (2005) the MRP acts as phase III of cellular detoxification mechanism, as described for metals such as arsenic, mercury and cadmium (Kala et al., 2000; Long et al., 2011; Zalups \& Bridges, 2010).

Few studies have investigated the modulation of these transporters in early stage of development in fish and use them as biomarkers of chemical exposure (Costa et al., 2012; Fischer et al., 2013; Long et al., 2011). The early stage of development is particularly sensitive to pollutants exposure (de Andrade Brito et al., 2018) but the majority of the studies are devoted to invertebrates (Faria et al., 2011; Roepke et al., 2006).

Fish embryo and larvae are more sensitive to environmental impacts, including toxic substances compared to the juveniles and adults (Barreto et al., 2020; de Andrade Brito et al., 2018). The intoxication sensitivity observed in early developmental stages of fish showed interesting endpoints that strongly suggest their use as biomarkers of exposure to single or complex mixtures of pollutants. The toxicity of copper to early developmental stages of fish were described in D. rerio embryos resulting in mortality, hatching inhibition, impairment of larval development and lateral line dysfunction (Cunha et al., 2016; Fischer et al., 2013). Despite of that, no data are available about the effects of low doses of copper in tropical fish and after parental administration.

The current study was carried out to investigate the influence of copper on the activity of $\mathrm{ABC}$ transporters (Pgp and MRP) during embryonic and larval development of the tropical fish species Rhamdia quelen after sub-chronic exposure of adult females.

\section{MATERIALS AND METHODS}

\section{Adult animals' exposure}

The experiment was conducted in the Laboratory of Reproductive Technology for Farmed Aquatic Animal (LATRAAC), at the Institute for Research in Environmental Aquaculture (InPAA), Western Paraná State University (UNIOESTE), Brazil. Twenty females of catfish Rhamdia quelen (weight $235.32 \pm 60.67 \mathrm{~g}$ ) were exposed to copper $\left(\mathrm{CuSO}_{4}+5 \mathrm{H}_{2} \mathrm{O}\right)(5 \mathrm{mg} \mathrm{kg}-1 \mathrm{fish})$. The metal was administered through oral gavage, one dose every 10 days for 60 days. This group is referred as "Cu". A " $\mathrm{C}$ " group $(\mathrm{n}=20)$ received the gavages containing only $\mathrm{NaCl} 0.9 \%$, medium used for copper solution preparation. For gavage procedures, fishes were previously anaesthetized with tricaine methane sulfonate (MS-222, 200mg L-1).

\section{Gametes collection and fertilization}

Six females from each group $(\mathrm{C}$ and $\mathrm{Cu})$, exhibiting a rounded abdomen, reddish urogenital papilla, and uniform oocyte color and size (Sanches et al., 2011) were used to obtain the oocytes. Spawning was induced by intramuscular injection of two doses of carp pituitary extract (CPE). The first injection comprised $0.5 \mathrm{mg}$ CPE kg-1 and twelve hours after a second dose of $5 \mathrm{mg}$ CPE kg-1 was injected (Bombardelli et al., 2006). The oocytes were collected $\left(10\right.$ hours at $24{ }^{\circ} \mathrm{C}$ after the second dose of the hormone injection) in petri dishes through abdominal ventral massage in the cephalocaudal direction.

A pool of semen from 6 individuals without copper exposure was used to fertilize the oocytes. Two hundred microliters of the semen pool were added to $3 \mathrm{~mL}$ of oocytes from each female ( $\mathrm{C}$ and $\mathrm{Cu}$ groups). Gametes were activated by adding $20 \mathrm{~mL}$ of water as described by Bombardelli et al. (2006). The fertilization was performed in duplicate for each treatment.

For the collection of embryos and larvae during the embryonic development, two water recirculation systems with controlled temperature $\left(27^{\circ} \mathrm{C}\right)$ were used. One system consisted of experimental incubators $(2.5 \mathrm{~L})$ where $30 \mathrm{mg}$ L-1 of copper was added (group named "Copper") Bombardelli et al., 2016). The other system was copper free (group named "Control”).

\section{Experimental groups}

The four experimental groups are described in the Table 1.

\section{ABC transporters activity}

The transport activity was analyzed in different stages from each group, using 6 samples of each of the following periods: oocytes $(300 \mu \mathrm{L}=$ approximately 200 oocytes $), 11$ hours post fertilization (hpf) eggs $(400 \mu \mathrm{L}=$ approximately 200 eggs), $36 \mathrm{hpf}$ embryos (100 individuals), and $96 \mathrm{hpf}$ larvae (100 individuals).

The activity of P-gp and/or MRPs were analyzed using the calcein-acetoxymethyl ester (CAL-AM) substrate in the absence and presence of specific inhibitors verapamil (P-gp) and MK571 (MRP) Di and Kerns, 2016; Pessatti and Fontana, 2013). CAL-AM is a nonfluorescent substrate of $A B C$ protein transporters, and its accumulation is inversely proportional to transporters activity. Inside the cell CAL-AM is converted into calcein (fluorescent) by sterases. The fluorophore is retained in the cell, not being a substrate for the $\mathrm{ABC}$ protein transporters. Thus, high fluorescence is indicative of low activity and low fluorescence means a high transport activity Essodaigui et al., 1998).

Table 1. Organization of the tested groups.

\begin{tabular}{lcc}
\hline Group name & $\begin{array}{c}\text { Adult female } \\
(5 \mathrm{mg} \mathrm{Cu} \mathrm{kg-1} \mathrm{fish})\end{array}$ & $\begin{array}{c}\text { egg, embryo, and larva } \\
(30 \mathrm{mg} \mathrm{Cu} \mathrm{L}-1)\end{array}$ \\
\hline $\mathrm{C}^{\text {Control }}$ & - & - \\
$\mathrm{Cu}^{\text {Control }}$ & + & - \\
$\mathrm{C}^{\text {Copper }}$ & - & + \\
$\mathrm{Cu}^{\text {Copper }}$ & + & + \\
\hline
\end{tabular}


The assays were carried out in transparent 24-well plates. Oocytes, embryos, and larvae were incubated for 30 minutes in the presence or absence of inhibitors: verapamil $(10 \mu \mathrm{M})$ or MK571 $(0.25 \mu \mathrm{M})$. After this period CAL-AM $(1 \mu \mathrm{M})$ was added for $60 \mathrm{~min}$. Plates were kept protected from light and under mild agitation during the incubation period. Then, samples were collected in vials tubes $(1.5 \mathrm{~mL})$ and kept at $-80{ }^{\circ} \mathrm{C}$. Subsequently the samples were lysed ( $300 \mu \mathrm{L}$ of Triton X-100 2\% / PBS) and centrifuged (10 min at $2500 \mathrm{x} \mathrm{g}$ ). One aliquot of the supernatant was separated for protein quantification (Bradford, 1976) and $200 \mu \mathrm{L}$ was used to determine fluorescence. Calcein fluorescence was measured using Tecan Genius microplate reader with filters as described: Excitation $\lambda=485 \mathrm{~nm}$, and Emission $\lambda=530 \mathrm{~nm}$. The protein concentration in the homogenates was determined using Bradford's method (Bradford, 1976) with bovine serum albumin as the standard.

\section{Fertilization and survival rates}

The fertilization rate was verified 11 hpf by counting, in a $1 \mathrm{~mL}$ sample of translucid and with visible embryonic development (fertilized eggs), and opaque or white eggs (non-fertilized eggs) under a stereomicroscope. The rate was calculated from triplicate of 200 eggs counting.

Four hundred hatched eggs from each group were separated and maintained until $96 \mathrm{hpf}$ to calculate the survival rate.

\section{Statistical procedures}

Data were evaluated using the GraphPad Prism 3 program. First, the Shapiro-Wilk test was performed to verify the normality of the data. For data presenting normal distribution, the ANOVA test was applied, followed by the pos hoc Tukey test for comparison between groups and genders, while for data without normal distribution the Kruskal-Wallis test was applied. The differences found between the groups were accepted as significant only for values of $p<0.05$.

\section{RESULTS}

\section{ABC transporters activity}

Oocytes from copper exposed females $\left(\mathrm{Cu}^{\text {Control }}\right)$ accumulated $50.5 \%$ less calcein than oocytes from control females $\left(\mathrm{C}^{\text {Control }}\right)$ (Figure 1A). In the presence of the P-gp specific inhibitor Verapamil the calcein concentration increased $77 \%$ in $\mathrm{C}^{\text {Control }}$ and $110 \%$ in $\mathrm{Cu}^{\text {Control }}$ oocytes, while the MRP inhibitor MRK 571 did not modified calcein accumulation in oocytes (Figure 1A).

Copper increased calcein accumulation in $11 \mathrm{hpf}$ eggs from control and exposed females (Figure 1B). Verapamil led to an increase in calcein accumulation in eggs not exposed to copper from both groups of females $\left(\mathrm{C}^{\mathrm{Control}}\right.$ and $\left.\mathrm{Cu}^{\mathrm{Control}}\right)$, and MK 571did not show inhibitory effect (higher accumulation of calcein) in all groups (Figure 1B).
In individuals $36 \mathrm{hpf}$ (larvae) (Figure 1C) the values of calcein accumulated did not changed in all groups $\left(\mathrm{C}^{\text {control }}\right.$, $\left.\mathrm{C}^{\text {copper }}, \mathrm{Cu}^{\text {control }}, \mathrm{Cu}^{\text {copper }}\right)$ in the absence of inhibitors. The presence of Verapamil did not increase calcein accumulation only in $C^{\text {copper }}$ group. The incubation with MK 571 increased the calcein accumulation in all groups but no difference was observed between $\mathrm{C}^{\text {control }}, \mathrm{Cu}^{\text {control }}$ and $\mathrm{C}^{\text {copper }}, \mathrm{Cu}^{\text {copper }}$.

After $96 \mathrm{hpf}$ (Figure 1D) the larvae from the unexposed female eggs in the absence of copper $\left(\mathrm{C}^{\text {control }}\right)$ accumulated more ca ul lcein in relation to $\mathrm{C}^{\text {copper}}, \mathrm{Cu}^{\text {control }}$ and $\mathrm{Cu}^{\text {copper }}$ groups and without inhibitors (Vrp and MK 571). The presence of verapamil increased the accumulation of calcein in all groups $\left(\mathrm{C}^{\text {control }}, \mathrm{C}^{\mathrm{copper}}, \mathrm{Cu}^{\text {control }}, \mathrm{Cu}^{\text {copper }}\right)$. The MK 571 inhibitor showed its inhibitory effect (higher accumulation) in all groups, and was more effective than Verapamil (Figure 1D).

\section{Fertilization and survival rates}

The fertilization rate was checked $11 \mathrm{hpf}$ (Figure 2A), when the blastopore closes. Eggs exposed to copper from females not exposed to copper $\left(\mathrm{C}^{\mathrm{copper}}\right)$ presented a reduced fertilization rate $(16.73 \%)$ compared to eggs not exposed from females not exposed $\left(\mathrm{C}^{\text {control }}\right)$. The decrease rate of fertilization was about $14.2 \%$, when comparing eggs exposed to eggs not exposed to copper, both from females exposed to copper $\left(\mathrm{Cu}^{\mathrm{Copper}} \mathrm{X} \mathrm{Cu}^{\mathrm{Control}}\right)$ (Figure 2A). The eggs exposure to copper $\left(\mathrm{C}^{\text {copper }}\right)$ decreased survival $(41.9 \%)$ compared to control group eggs $\left(\mathrm{C}^{\text {control }}\right)$ (Figure $\left.2 \mathrm{~B}\right)$.

\section{DISCUSSION}

Most studies about $\mathrm{ABC}$ transporters have been developed in somatic cells in terms of functionality of these proteins (Fischer et al., 2011; Diaz de Cerio et al., 2012), but the characterization of the mechanism is not yet completely elucidated in fish. Particularly the studies are scarcer during the early stages of development where the fish is supposed more sensitive to chemicals exposure (Barreto et al., 2020). In the present study the activity of proteins $\mathrm{ABC}$ transporters in different stages of development of $H$. quelen, oocytes, embryos and larvae were investigated after incubation of two well-known modulators compounds Verapamil and MK571 (Pessatti \& Fontana et al., 2013) also described by Cunha et al. (2016) in D. rerio.

In Rhamdia quelen the oocytes efflux activity was most effectively blocked (higher accumulation) by the presence of verapamil (P-gp inhibitor) but no apparent activity by blocking using the MK571 inhibitor (MRPs) was found. This finding support that the $\mathrm{ABC}$ (P-gp) transcripts were found in the initial stages of development in the species, indicating a gene maternally transferred to the embryo where the efflux activity can be already observed even 1 hpf (Fischer et al., 2013). Similarly, MRPs transcripts (abcc1, abcc5) were also maternally transferred in zebrafish eggs (Long et al., 2011; Fischer et al., 2013). Although the presence of eggs transcripts also was described by Faria et al. (2011) this event was only observed in larvae of D. rerio after 1-day hatching. 

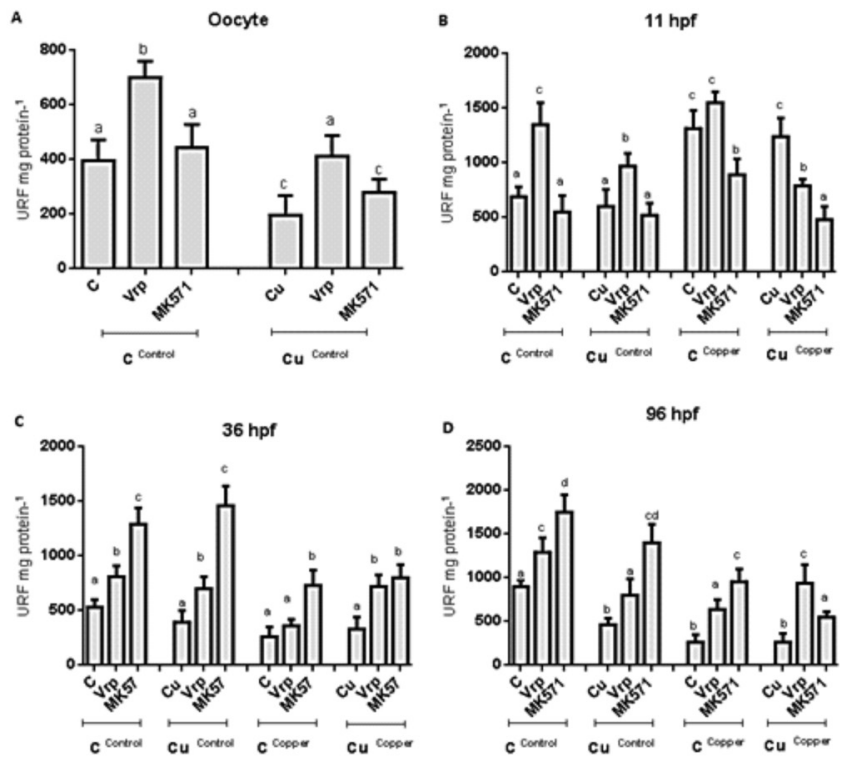

Figure 1. Calcein accumulation in Rhamdia quelen oocytes, embryos, and larvae after inorganic copper exposure. A) Oocytes. B) Embryos $11 \mathrm{hpf}$. C) Larvae 36 hpf. D) Larvae 96 hpf. Different letters mean different values among groups $(\mathrm{p}<0.05)$.
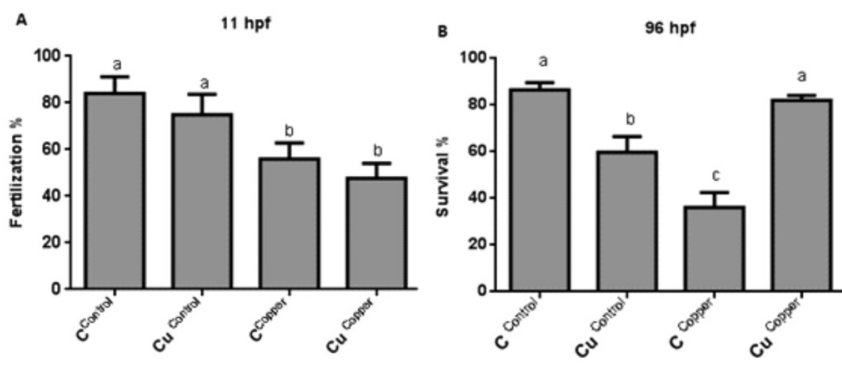

Figure 2. Fertilization (A) and survival (B) rates Rhamdia quelen eggs after exposure to inorganic copper. Different letters mean different values among groups $(\mathrm{p}<0.05)$.

Quantitative real-time PCR (qRT-PCR) analyze shows that the abcc1 and abcb1 genes are rarely transcript and their levels only increase 90-120 minutes after fertilization in Strongylocentrotus purpuratus (sea urchin) embryos. Instead, the efflux activity increases by $25 \mathrm{~min}$ post-fertilization and the increase was kept in the presence of inhibitors of protein synthesis and mRNA (Hamdoun et al., 2004). These data indicate that the regulation of efflux activity in the initial stages is post-translational.

With the blocked efflux by MK571 showing that the ABC proteins activity can be reversed in 36 hpf larvae also kept 96 hpf (last analyzed stage), the current data suggest a temporal distribution of this mechanism of transport in early stages of development, as this finding was confirmed by Verapamil blocking. The most apparent modulation of MRP-1 in the final stages of development ( $96 \mathrm{hpf}$ ) may be related to the protein physiological function in the tissues, as intestine, kidney and liver completely developed at this stage. Cunha et al. (2016) found in D. rerio the abcc gene being detected mainly at $72 \mathrm{hpf}$ where the organogenesis is already completed for this species.
According to the literature, the time profile of the transporter activation seems to present an interspecific characteristic. Hamdoun et al. (2002) using calcein - AM and the MK571 inhibitor described a shortly transporter activity after fertilization in sea urchin embryos. Similar condition was described by McFadzen et al. (2000) in fertilized Mytilus edulis embryos where the Rhodamine B accumulated in the presence of a Pgp inhibitor (Verapamil), while Toomey and Epel (1993) did not find the presence of this protein in urchin sea larvae (Anamesus lytechinus) or even the efflux capacity.

In the current study after chronic exposure of females to copper, the lowest accumulation of calcein in oocytes collected in relation to non-exposed female oocytes, could be explained by the increased activity of proteins $A B C$ transporters (Pgp and MRPs). This finding is due to the presence of mRNA from females and the consequent expression of $\mathrm{ABC}$ transporter proteins. Others have described the increase of $\mathrm{ABC}$ transporter proteins after exposure to metals as coral $(\mathrm{Cu})$, copepods $(\mathrm{Cu}$ and Cd), Antarctic fish Trematomus Bernacchi and oyster C. virginica exposed to Cd (Ivanina \& Sokolova, 2008; Venn et al., 2009; Zucchi et al, 2010; Della Torre et al., 2012; Jeong et al., 2014). However, embryos exposed to copper after $11 \mathrm{hpf}$ without the influence of maternal exposure showed the efflux activity of calcein - AM inhibition. Wu et al. (2015) reported an increase in calcein accumulated in Lytechinus pictus embryos (sea urchin) in blastula stage also by exposure to copper, corroborating the results in the present study. The literature regarding the influence of pollutants on $\mathrm{ABC}$ transporters in early stages of development is still scarce. The evidence of copper exposure may disturb the transporter mechanisms on earlier stages of development in fish is an important highlight in environmental toxicology. In general, during the early stages fish are very sensible to chemical exposure and the consequence for adult population is unpredictable (Brito et al., 2018; Barreto et al., 2020).

After the larvae formation in Rhamdia quelen (36 and 96 hpf) the inhibition of transporter proteins might be reversed as evidenced by calcein accumulation decreasing. This is quite different if embryos are exposed and not females when, a higher accumulation is observed. During these stages the activity of MRP is inducted as demonstrated by the lower accumulation of calcein, but these findings do not interfere with the larvae survival rate.

The copper induction transporter proteins and the role of P-gp in the detoxification was confirmed by Li et al. (1997). The increase in copper concentration in gill and mantle on the oyster Crassostrea angulata was significantly higher after the interference of the abcb1 gene. Wu et al. (2015) described an inhibition of MRP activity significantly increasing the copper concentration showing that $\mathrm{ABC}$ transporters can dislocate copper to outside of the cell while Cui et al. (2007) described the participation of different transporters proteins 
involved in metal detoxification. This mechanism may utilize the $\mathrm{ABC}$ transporter proteins to remove glutathione (GSH) complexes with metals (Cole and Deeley, 2006), or by other metabolites generated in the cell due to exposure to toxic agents that activates this mechanism of transport. Some authors as Vollrath et al. (2006) have suggested that the induction of $\mathrm{ABC}$ genes can be related to the ability of metals to produce ROS and consequently increasing its transport from cell. The ROS production would be responsible for the activation of nuclear factor Nrf2 which binds to sequences ARE (antioxidant response element) and regulates a battery of antioxidant genes (Kang et al., 2005; Adachi et al., 2007).

The current study is in agreement with other where the MXR activity is quite high in embryo and larval stages of different aquatic animals. The data suggest that the earlier stages may be more sensible to pollutant exposure by $\mathrm{ABC}$ transporters proteins inhibition. This evidence allows the development of studies where the synergism found in complex mixtures (greater environmental relevance) can act as chemosensitizers (blockers). The importance of characterizing the modulation of proteins in different stages of development is due to the proposed use of the MXR activity as a biomarker. As discussed in the present study, there is a temporal modulation of $\mathrm{ABC}$ transporter proteins throughout the development. These findings if properly applied, could reveal the role of transporter proteins in the earlier stage of development in fish as an important biomarker in aquatic toxicology studies and fish cultivation.

\section{ACKNOWLEDGMENTS}

The authors thank CAPES (Brazilian Ministry Educational Council) for fellowship assistance and CNPq (Brazilian Agency for Science and Technology) for grants.

\section{REFERENCES}

ADACHI, W., SUZUKI, N. N., FUJIOKA, Y., SUZUKI, K., OHSUMI, Y, INAGAKI \& F. 2007. Crystallization of Saccharomyces cerevisiae aminopeptidase 1, the major cargo protein of the Cvt pathway. Acta Cryst. F63: 200-203. https:// doi.org/10.1107/S1744309107005441

BARRETO, L.S., SOUZA, A.T.C., MARTYINS, C.C., ARAUJO, S.B.L. \& OLIVEIRA RIBEIRO, C.A. 2020. Urban effluents affect the early development stages of Brazilian fish species with implications for their population dynamics. Ecotoxicol. Environ. Safety, 188, p. 109907. https://doi.org/10.1016/j. ecoenv.2019.109907

BOMBARDELLI, R. A., NEUMANN, G., TOLEDO, C. P. R., SANCHES, E. A., BASTOS, D. N., OLIVEIRA\& J. D. SILVA. 2016. Sperm motility, fertilization, and larval development of silver catfish (Rhamdia quelen) in coppercontaminated water. Semina. Ciências Agrárias. 37: 1667-1678. http://dx.doi.org/10.5433/1679-0359.2016v37n3p1667

BOMBARDELLI, R.A.; MÖRSCHBÄCHER, E.F.; CAMPAGNOLO, R.; SANCHES, E.A. \& SYPERRECK, M.A. 2006. Insemination dose for artificial fertilization of grey jundiá oocytes, Rhamdia quelen (Quoy \& Gaimard, 1824). Rev Brasil Zoot. 35 (4): 1251-1257. https://doi.org/10.1590/S151635982006000500001
BOSNJAK, I., UHLINGER, K.R., HEIM, W., SMITAL, T., FRANEKICI, C.I., CEOLICI, J., COALE, K., EPEL, D. \& HAMDOUN, A. 2009. Multidrug efflux transporters limit accumulation of inorganic, but not organic, mercury in Sea Urchin embryos. Environ Sci Technol 43: 8374-8380. https:// doi.org/10.1021/es901677r

BRADFORD, M. 1976. A rapid and sensitive method for the quantification of microgram quantities of protein utilizing the principle of protein-dye binding. Anal. Biochem. 72: 248-254. https://doi.org/10.1006/abio.1976.9999.

BRITO, I. A., GARCIA, J. R. E., SALAROLI, A. B., FIGUEIRA, R. C. L., MARTINS, C. C., CORDEIRO NETO, A., GUSSOCHOUERI, P. K., CHOUERI, R. B., ARAUJO, S. B. L. \& OLIVEIRA RIBEIRO, C. A., 2018. Embryo toxicity assay in the fish species Rhamdia quelen (Teleostei, Heptaridae) to assess water quality in the upper Iguaçu basin (Paraná, Brazil). Chemosphere 208, p. 207-218. https://doi.org/10.1016/j. chemosphere.2018.05.009

COLE, S.P.C. \& DEELEY, R.G. 2006. Transport of glutathione and glutathione conjugates by MRP1. Trends Pharmac. Sci. 27 (8): 438-446. https://doi.org/10.1016/j.tips.2006.06.008.

COSTA, J., REIS-HENRIQUES, M.A., CASTRO, L.F.C. \& FERREIRA, M. 2012. ABC transporters, CYP1A and GSTa gene transcription patterns in developing stages of the Nile tilapia (Oreochromis niloticus). Gene. 506: 317-324. https://doi. org/10.1016/j.gene.2012.06.092

CUI, S., OTTEN, C., ROHR, S., ABDELILAH-SEYFRIED, S. \& LINK, B.A. 2007. Analysis of aPKClambda and aPKCzeta reveals multiple and redundant functions during vertebrate retinogenesis. Molec. Cell. Neurosci. 34(3): 431-444. https://doi. org/10.1016/j.mcn.2006.11.016

CUNHA, V., RODRIGUES, M., SANTOS, M., MORADASFERREIRA, P. \& FERREIRA, M. 2016. Danio rerio embryos on Prozac Effects on the detoxification mechanism and embryo development. Aquatic Toxicol. 178: 182-189. https://doi. org/101016/j.aquatox.2016.08.003

DEAN, M. \& ANNILO, T. 2005. Evolution of the ATP-binding cassette $(\mathrm{ABC})$ transporter superfamily in vertebrates. Ann Rev Genomics Hum Genet. 6: 123-142. https://doi.org/10.1146/ annurev.genom.6.080604.162122.

DELLA TORRE, C., ZAJA, R., LONCAR, J., SMITAL, T., FOCARDI, S. \& CORSI, I., 2012. Interaction of ABC transport proteins with toxic metals at the level of gene and transport activity in the PLHC-1 fish cell line. Chem. Biol. Interact. 198: 9-17. https://doi.org/10.1016/j.cbi.2012.04.008.

DIAZ DE CERIO, O., BILBAO, E., CAJARAVILLE, M.P. \& CANCIO, I. (2012). Regulation of xenobiotic transporter genes in liver and brain of juvenile thick lip grey mullets (Chelon labrosus) after exposure to Prestige-like fuel oil and to perfluorooctane sulfonate. Gene. 498: 50-58. https://doi. org/10.1016/j.gene.2012.01.067

ESSODAIGUI, M., BROXTERMAN, H.J. \& GARNIERSUILLEROT, A. 1998. Kinetic analysis of calcein and calceinacetoxymethylester efflux mediated by the multidrug resistance protein and P-glycoprotein. Biochemistry 37: 2243 - 2250. https://doi.org/10.1021/bi9718043.

FARIA, M., NAVARRO, A., LUCKENBACH, T., PIÑA, B. \& BARATA, C. (2011). Characterization of the multixenobiotic resistance (MXR) mechanism in embryos and larvae of the zebra mussel (Dreissena polymorpha) and studies on its role in tolerance to single and mixture combinations of toxicants. Aquat. Toxicol. 101:78-87. https://doi.org/10.1016/j.aquatox.2010.09.004

FISCHER, S., KLUVER, N., BURKHARDT-MEDICKE, K., PIETSCH, M., SCHMIDT, A. \& M. WELLNER, P. 2013. 
Abcb4 acts as multixenobiotic transporter and active barrier against chemical uptake in zebrafish (Danio rerio) embryos. BMC Biol. 11: 69. https://doi.org/10.1186/1741-7007-11-69

FISCHER, S., LONCAR, J., ZAJA, R., SCHNELL, S., SCHIRMER, K. \& SMITAL, T. 2011. Constitutive mRNA expression and protein activity levels of nine $\mathrm{ABC}$ efflux transporters in seven permanent cell lines derived from different tissues of rainbow trout (Oncorhynchus mykiss). Aquat. Toxicol. 101: 438-446. https://doi.org/10.1016/j.aquatox.2010.11.010

HAMDOUN, A. M., GRIFFIN, F. J. \& CHERR, G. N. 2002. Tolerance to biodegraded crude oil in marine invertebrate embryos and larvae is associated with expression of a multixenobiotic resistance transporter. Aquat. Toxicol. 61, 127-140. https://doi. org/10.1016/S0166-445X(02)00050-4

HAMDOUN, A.M., CHERR, G.N., ROEPKE, T.A. \& EPEL, D. 2004. Activation of multidrug efflux transporter activity at fertilization in sea urchin embryos (Strongylocentrotus purpuratus). Dev Biol. 276: :52-462. https://doi.org/10.1016/j. ydbio.2004.09.013.

IVANINA, A.V. \& SOKOLOVA, I.M. 2008. Effects of cadmium exposure on expression and activity of P-glycoprotein in eastern oysters, Gmelin. Aquat. Toxicol. 88: 19-28. https://doi. org/10.1016/j.aquatox.2008.02.014

JEONG, C.B., KIM, B.M., LEE, J.S. \& RHEE, J.S., 2014. Genomewide identification of whole ATP-binding cassette (ABC) transporters in the intertidal copepod Tigriopus japonicus. BMC Genomics 15: 651. https://doi.org/10.1186/1471-2164-15-651

KALA, S.V., NEELY, M.W., KALA, G., PRATER, C.I., ATWOOD, D.W., RICE, J.S. \& LIEBERMAN, M.W. 2000. The MRP2/cMOAT transporter and arsenic-glutathione complex formation is required for biliary excretion of arsenic. J. Biol. Chem. 275: 33404-33408. https://doi.org/10.1074/jbc. M007030200.

KANG, K.W., LEE, S.J. \& KIM, S.G. 2005. Molecular mechanism of nrf2 activation by oxidative stress. Antioxid. Redox Signal. 7: 1664-1673. https://doi.org/10.1089/ars.2005.7.1664.

LI, X., ZHANG, G., NGO, N., ZHAO, X., KAIN, Sr \& HUANG, C.C. 1997. Deletions of the Aequorea victoria Green Fluorescent Protein Define the Minimal Domain Required for Fluorescence. J. Biolog Chem. 272(45): 28545-28549. https://doi.org/ https:// doi.org/10.1074/jbc.272.45.28545

LITMAN, T., DRULEY, T.E., STEIN, W.D. \& BATES, S.E. 2001. From MDR to MXR: new understanding of multidrug resistance systems, their properties and clinical significance. Cell Mol Life Sci 58: 931-959. https://doi.org/10.1007/PL00000912

LOCKER, K. 2016. Mechanistic diversity in ATP-binding cassette (ABC) transporters. Nat. Struc.t Mol. Biol.: 23, 487-493. https:// doi.org/10.1038/nsmb.3216.

LONCAR, J., POPOVIC, M., ZAJA, R. \& SMITAL, T. 2010. Gene expression analysis of the ABC efflux transporters in rainbow trout (Oncorhynchus mykiss). Comp. Biochem. Physiol. C-Toxicol. Pharmacol. 151: 209-215. https://doi.org/10.1016/j. cbpc.2009.10.009

LONG, Y., LI, Q., ZHONG, S., WANG, Y. \& CUI, Z. 2011. Molecular characterization and functions of zebrafish ABCC2 in cellular efflux of heavy metals. Comp. Biochem. Physiol. C Toxicol. Pharmacol. 153: 381-391. https://doi.org/10.1016/j. cbpc.2011.01.002.

MCFADZEN, I., EUFEMIA, N., HEATH, C., EPEL, D., MOORE, M. \& LOWE, D. 2000. Multidrug resistance in the embryos and larvae of the mussel Mytilus edulis. Mar. Environ. Res. 50: 319 323. https://doi.org/10.1016/s0141-1136(00)00057-x

OOSTERHUIS, B., VUKMAN, K., VAGI, E., GLAVINAS, H.,
JABLONKAI, I. \& KRAJCSI, P. 2008. Specific interactions of chloroacetanilide herbicides with human $\mathrm{ABC}$ transporter proteins. Toxicology 248:45-51. https://doi.org/10.1016/j. tox.2008.03.003

PESSATTI, M.L. \& FONTANA, J.D. 2013. Multixenobiotic resistance mechanism monitoring: standardization of fluorescence emitted by Rhodamine B. Ecotoxicol. Environ. Contam. 8 (1): 101-104. https://doi.org/10.5132/eec.2013.01.014

ROEPKE, T.A., HAMDOUN, A.M. \& CHERR, G.N. 2006. Increase in multidrug transport activity is associated with oocyte maturation in sea stars. Dev. Growth Differ. 48: 559-573. https:// doi.org/10.1111/j.1440-169X.2006.00893.x

SANCHES, E.A., NEUMANN, G., BAGGIO, D.M., BOMBARDELLI, R.A., PIANA, P.A. \& ROMAGOSA, E. 2011. Time and temperature on the storage of oocytes from jundiá catfish, Rhamdia quelen. Aquaculture. 319 (3-4): $453-$ 458. https://doi.org/10.1016/j.aquaculture.2011.07.036

SURESH, V. AMBUDKAR, C.K., SAUNA, Z., \& GOTTESMAN, M.M. 2003. P-glycoprotein: from genomics to mechanism. Oncogene. 22: 7468-7485. https://doi.org/10.1038/ sj.onc. 1206948 .

SZAKÁCS, G., VÁRADI, A., ÖZVEGY-LACZKA, C. \& SARKADI, B. 2008. The role of ABC transporters in drug absorption, distribution, metabolism, excretion and toxicity (ADME-Tox). Drug Discov. Today 13: 379-393. https://doi. org/10.1016/j.drudis.2007.12.010

TOOMEY, B.H. \& EPEL, D. 1993. Multixenobiotic resistance in Urechis caupo embryos - protection from environmental toxins. Biol. Bull. 185: 355-364. https://doi.org/10.2307/1542476.

VENN, A.A., QUINN, J., JONES, R. \& BODNAR, A. 2009. P-glycoprotein (multi-xenobiotic resistance) and heat shock protein gene expression in the reef coral Montastraea franksi in response to environmental toxicants. Aquat. Toxicol. 93: 188195. https://doi.org/10.1016/j.aquatox.2009.05.003

VOLLRATH, V., WIELANDT, A.M., IRURETAGOYENA, M. \& CHIANALE, J. 2006. Role of Nrf2 in the regulation of the Mrp2 (ABCC2) gene. Biochem. J. 395: 599-609. https://doi. org/10.1042/bj20051518

WU, B.T., WEN, S.H., HWANG, S.P., HUANG, C.J. \& KUAN, Y.S. 2015. Control of Wnt5b secretion by wntless modulates chondrogenic cell proliferation through fine-tuning fgf3 expression. J. Cell Sci. 128 (12): 2328-2339. https://doi. org/10.1242/jcs. 167403

XU, C., LI, Y.C. \& KONG, A.T. 2005. Induction of phase I, II and III drug metabolism/transport by xenobiotics. Arch. Pharm. Res. 28: 249-268. https://doi.org/10.1007/BF02977789.

ZAJA, R., MUNIC, V., KLOBUCAR, R. S., AMBRIOVICRISTOV, A. \& SMITAL, T. 2008. Cloning and molecular characterization of apical efflux transporters (ABCB1, $\mathrm{ABCB} 11$ and $\mathrm{ABCC} 2$ ) in rainbow trout (Oncorhynchus mykiss) hepatocytes. Aquat. Toxicol. 90: 322-332. https://doi. org/10.1016/j.aquatox.2008.09.012

ZALUPS, R.K. \& BRIDGES, C.C. 2010. Seventy-five percent nephrectomy and the disposition of inorganic mercury in 2 , 3-dimercaptopropanesulfonic acid-treated rats lacking functional multidrug-resistance protein 2. J. Pharmacol. Exp. Ther. 332: 866-875. https://doi.org/10.1124/jpet.109.163774.

ZUCCHI, S., CORSI, I., LUCKENBACH, T., BARD, S.M., REGOLI, F. \& FOCARDI, S. 2010. Identification of five partial ABC genes in the liver of the Antarctic fish Trematomus bernacchii and sensitivity of $\mathrm{ABCB} 1$ and $\mathrm{ABCC} 2$ to $\mathrm{Cd}$ exposure. Environ. Pollut. 158:2746-2756. https://doi.org/10.1016/j. envpol.2010.04.012. 